\title{
LABOR FORCE BETWEEN DESIDERATUM AND REALITY
}

\author{
Adina MIHĂILESCU ${ }^{1}$
}

DOI: 10.35782/JCPP.2020.3.03

\begin{abstract}
The scientific approach of the study follows two perspectives on the labor market: a first analysis is dedicated to the employees absorbed on the labor market and of the companies that benefit from European funds in order to get out of the world economic crisis more easily. According to the National Institute of Statistics, the number of employees in the Romanian economy reached 4.984 million employees in September 2019, compared to 4.943 million employees in September 2018. New employment in the construction, wholesale and retail sectors, health and social assistance, hotels and restaurants, transport and storage, IT and consulting led to an increase in the number of employees in the economy by 41,000 between September 2018 and September 2019. The sectors that helped the economy reach the threshold of 5 million employees in 2020 were the constructions from public and private investments and the manufacturing industry. The second perspective of the study aims at the standard of living of employees' households and the purchasing power of their incomes in order to cover not only the basic needs of food, clothing, housing, its maintenance, but also the satisfaction of having a social life, of evolve professionally, to go out with family on the weekend, to meet relatives or friends, etc.
\end{abstract}

Keywords: labor force, education, professional skills, unemployment, vulnerable groups.

\section{Introduction}

In Romania, the areas where connectivity is good, where significant investment is made in infrastructure and where foreign direct investment rates are high, the level of economic growth and the level of average wages are high. Lack of digital connectivity and adequate infrastructure further deepens disparities between and within regions, and

\footnotetext{
${ }^{1}$ Senior Researcher, The Research Institute for Quality of Life; E-mail: adina.mihailescu@ yahoo.com yahoo.com
} 
education and training can make a positive contribution to improving market competitiveness.

In the period 2014-2020, Romania's financial allocation from EU cohesion policy funds amounts to 26.8 billion euros, which represents about $2 \%$ of annual GDP. The programs in Romania in which 888 million Euro EU funds were allocated, in 2019, were for smart growth (2.7 billion euros); for sustainable growth and sustainable transport (13 billion euros); to increase labor inclusion (EUR 6.2 billion) ${ }^{1}$

Increasing the absorption rate of EU funds would make it easier for beneficiary states to emerge from the global economic crisis. European countries that have strong institutions and consistently promote economic and social policies appropriate to European integration and their own development will benefit more from these EU funds and reach a "saturation point" after a longer period. (Cace C. et al., 2010, p. 87101). Until 2019, the investments made with the help of EU funds in Romania led to the reconstruction of $318 \mathrm{~km}$ of Trans-European Transport Network (TEN-T) railway lines, to the start of works on 4,364 km of new or rebuilt roads, between which $692 \mathrm{~km}$ in the TEN-T network and the reconstruction and modernization of four airports. 2,708 micro and small and medium-sized enterprises, as well as 178 social enterprises, also received support; approximately 350,000 people have integrated into the labor market, benefiting from educational services.

\section{Labor force as desideradum}

In 1990, Romania had over 8 million employees, and at the opposite pole, the worst level of the number of employees was registered in 2011, when there were 4.095 million employees. The crisis years 2008-2009 "erased" more than 740,000 jobs from the economy. ${ }^{2}$ Romania has one of the lowest labor force participation rates in the EU, and its working age population has been steadily declining since 2008, while the labor force and skilled labor shortages have widened.

The year 2019 brought other rather bad news for the industry; ArcelorMittal Hunedoara Company with 640 employees have suspended production from December 1, 2019 and the platform Bucharest Heavy Machinery Company with 400 employees, announced that it will close in 2020. The latest data show that the number of employees in the industry decreased by 23,000 employees, from September 2018 to September 2019. In 2018, the share of long-term unemployment in the total

${ }^{1}$ https://ec.europa.eu/info/sites/info/files/2020-european_semester_country-report-romania_ro.pdf, accesat 05.09.2020, European Commission Brussels, Commission staff working document, 2020 Country Report on Romania, SWD (2020) 522 final).

2 https://www.zf.ro/zf-24/2020-un-an-crucial-pentru-piata-muncii-se-va-atinge-pragul-de-5-mil-desalariati-pentru-prima-data-in-ultimii-20-de-ani-sau-nu-18677589. 
unemployment rate increased to $44.1 \%$, after falling from $50 \%$ in 2016 to $41.4 \%$ in 2017.

Currently, about 100,000 long-term unemployed are registered with the public employment services. $88 \%$ of them come from rural areas, about $9 \%$ are Roma and over $90 \%$ are identified as having a low level of employment. The percentage of young people who are not employed and do not follow an education or training program (NEET) was $14.5 \%$ in 2018, one of the highest in the EU. The employment rate (among people aged 15 to 64) is still among the lowest in the EU, especially among women (58.7\% in Q3-2019, compared to 77.9\% among men) and people with a low level of training (43.8\% in Q3-2019, compared to $88.8 \%$ among those with a high level of training $)^{1}$

As nominal wages rose at a faster pace than inflation, this increase was also reflected in real wages, increasing their purchasing power. In 2018, the nominal remuneration per employee increased by $16.3 \%$, and as a result of rapid increases in public sector wages and minimum wage increases.

In the period 2015-2019, the minimum wage increased from $975 \mathrm{RON}$ (210 euros) to 2,080 RON (442 euros), in January 2020 being increased again to 2,230 RON (496 euros). About $20 \%$ of people who have a full-time contract receive the minimum wage. Romania, together with Bulgaria and Lithuania, recorded minimum wages more than twice higher in real terms compared to 2010 (Eurofund, 2019).

According to the National Institute of Statistics, the number of employees in the economy reached 4.984 million employees in September 2019, compared to 4.943 million employees in September 2018. The labor market could reach 5 million employees in 2020 (NIS, 2019). The steady increase in the number of employees over the past five years has come despite criticism of raising the minimum wage in the economy, saying that forcing employers to give a higher minimum wage will reduce their potential to create new jobs. In fact, the increase in the minimum wage determined those who were not interested enough to enter the labor market. New employment in the construction, wholesale and retail, health and social care, hotels and restaurants, transport and storage, IT and Consulting sectors has led to an increase in the number of employees in the economy by 41,000 between September 2018 and September 2019. "For two years Romania has been in a favorable situation from an economic point of view, and the percentage of the working population is at a record level. In the short term, the most important thing is economic growth. Romania has had an uninterrupted economic growth in the last seven years, which has determined this degree of

${ }^{1}$ https://ec.europa.eu/info/sites/info/files/2020-european_semester_country-report-romania_ro. pdf, accesat 05.09.2020, European Commission Brussels, Commission Working Document, 2020 Country Report on Romania, SWD (2020) 522 final 
employment. If this economic growth continues, it is possible to reach a number of 5 million employees" (Cepăreanu A., 2020).

Public investment could lead to a faster growth in the number of employees in the economy. The sectors that could help the economy reach the threshold of 5 million employees in 2020 are the construction sector based on public and private investment and the manufacturing industry. "The greatest growth potential is in construction and the food industry because our agriculture is strong, but it is not coupled with a manufacturing industry that brings added value." (Cepăreanu A., 2020).

The number of employees could also increase from the number of social workers who are able to work. They could enter the labor market and solve part of the labor shortage problem, which would translate into both increasing the number of Romanian employees and the state budget. The number of employees in the economy is important for the increase of the employed population and for the increase of the activity rate. Romania has only about 5 million employees with a population of 20 million, while Bulgaria and the Czech Republic have a population of 10 million and a number of employees similar to Romania. The increase in the number of employees in the economy brings more income to the budget by paying higher social contributions and taxes and slows down the migration of Romanians abroad. Also, job creation is an indicator pursued in international markets, for example the US stock market reacts immediately to the publication of the new job creation indicator in the US.

Public employment services are not effectively adapted to individual needs and are not integrated with social services, despite the fact that substantial funds are available. The percentage of young people who are not employed and do not attend any education or training program is among the highest in the EU. In 2018, 14.5\% of young people (1529 years old) were not employed and did not follow any education or training program (NEET), compared to the EU average of $14.5 \%$. More than a third of them were discouraged workers, short-term and long-term unemployed (European Commission, 2019i). About $69 \%$ of young NEETs remain inactive.

In 2018, the share of active women (15-64 years old) was 58.7\% (EU average being $68.7 \%$ ), compared to $7.9 \%$ for men (EU average being $79.4 \%$ ). The lowest activity rates were recorded among younger women (aged 15 to 24) and older women (aged 55 to 64 ). About $12 \%$ of women were inactive due to personal and family responsibilities. In 2018, the gender disparity in terms of employment among people with a child under the age of six was $29 \%$.

The high drop-out rate and the inadequacy of childcare facilities and services affect women's participation in the labor market, especially in rural areas. In the context of rising labor demand and declining unemployment, labor shortages persist in some sectors. In the first three quarters of 2019 , enterprises in the services sector $(9.8 \%)$, 
construction $(25.1 \%)$ and industry $(13.7 \%)$ mentioned that the labor shortage is a factor hindering the production (European Commission, 2019f) which is in increase compared to 2018 .

The mismatch between the demand and supply of skills has persisted in recent years. The European Competence Index, which measures the performance of EU competence systems, shows that Romania is among the countries with the lowest results, especially in terms of skills development and activation (CEDEFOP, 2019). In addition, the occurrence of vertical discrepancies (overqualification rate), although still below the EU average, has almost doubled in the last decade. Thus, in 2018, 18\% of workers with tertiary qualifications were employed in positions that did not require this level of qualification, while $28 \%$ of employees aged between 25 and 34 with tertiary education held a job for which this type of study was necessary, but their education or skills did not meet the requirements of the job (Eurostat, 2019a). This indicates a growing gap between education and work. Technological changes are expected to lead to a reorientation of demand towards higher skills and qualifications, which may not be fully covered by the current labor supply, given the time needed to adjust the education and training system.

In 2018, almost 2.3 million people (21.5\% of adults) had a low level of education. In 2018 , only $0.9 \%$ of adults aged between 25 and 64 had a recent learning experience (the EU average being $11.1 \%$ ). This is particularly worrying, given the small number of jobs available that require only a basic level of education. Recently, attempts have been made to address the issue of skills development and retraining. A new regulation on quality assurance in adult learning is also being developed. Expenditure on education remains among the lowest in the EU (2.8\% of GDP compared to the EU average). Persistent problems related to the acquisition of basic skills at school and the low level of digital literacy of the population are a challenge for the integration of future graduates into the labor market. Enrollment rates at all levels of education remain significantly below the EU average.

Both the Ministry of Education and the Presidential Administration have presented ideas for important reforms of the education system, but these have not yet been put into practice. Delays in streamlining and modernizing school infrastructure can affect the quality of education. It is estimated that the school age population will decrease by $10 \%$ by 2030 . In the period $2000-2016$, Romania closed $25 \%$ of schools and $17 \%$ of satellite schools (World Bank, 2018). However, 58\% of schools still have a surplus of built space, while $22 \%$ of students study in overcrowded schools, especially in urban areas (MEN, 2019). In addition, equity challenges are not addressed effectively, long walking distances to schools and kindergartens in rural areas and commuting costs are barriers to access to education. 
Reduced participation in education and early care accentuates inequality of opportunity among students. Only $15.7 \%$ of children under the age of three are enrolled in formal childcare services. In the case of children between the ages of four and the age of compulsory schooling, participation increased to $89.6 \%$ in 2017 , but remains below the EU average (95.4\%). Romania is among the last EU countries in the 2018 PISA survey in terms of average results in mathematics, science and reading (OECD, 2019a). Only $10.1 \%$ of the adult population has digital skills above the basic level, the lowest percentage in the EU (European Commission, 2019g).

The coverage of the kindergarten network has improved, but the disparities between rural and urban areas persist. Although, there are some improvements, the rate of early school leaving remains very high, deepening existing socio-economic disparities. The rate of people leaving early education and training was $16.4 \%$ in 2018, almost 6 percentage points above the EU average. This rate is particularly high in rural areas (about 25\%) (European Commission, 2019g) in the case of Roma (European Commission, 2019h) and children with disabilities (European Commission, 2019i). Students with a disadvantaged socio-economic situation, supported by school scholarships have a higher school participation rate. A concrete case is the allocation by the private company OMV-PETROM of scholarships to students, who choose vocational education and which has led to an increase in the school participation rate, especially of children from rural areas (Neagu G., 2016, p.379).

Regional disparities persist, with the highest rates of early school leavers being in the South-East and North-East regions, which also face the highest levels of poverty. The high rate of people leaving the education and training system early in some regions is correlated with low levels of urbanization (eg the North-East region). The most relevant data are those that reflect the situation of students according to the environment of residence and highlight the inequalities between urban and rural areas in terms of education: the chances that students in rural areas will continue their secondary education and follow a prestigious chain are much less numerous than their colleagues in the urban area (Neagu G., 2019, p. 86)

Romania also ranks first in the EU in terms of early school leaving among girls $(16.1 \%$ compared to the EU average of 8.9\%), which is a challenge from the perspective of the likely future persistence of already high gender disparities in employment. Comprehensive measures have not yet been put in place to combat early school leaving by providing appropriate support to vulnerable students. The gross enrollment rate in kindergarten (3-6 years) was $85 \%$ in rural areas, compared to $97.4 \%$ in urban areas (European Commission, 2019g). Only 37\% of Roma children are enrolled in preschool education (European Commission, 2019h). The rate is $15 \%$ in cities and $4.2 \%$ in municipalities (European Commission, 2019i). According to data from 2016, 53\% of Roma have only completed primary education (FRA, 2016). 
The rate of early school leaving for people with disabilities is $41.4 \%$, one of the highest in the EU and twice the EU average (19.6\%), while the tertiary education rate $(22.6 \%)$ is well below the EU average (32.4\%).

Lower levels of education are in rural and economically disadvantaged areas, including those with a large Roma population. The disadvantaged categories are good to participate in education from the first years, to attend kindergarten and to be supported with educational programs: "Psychologists and pedagogues have shown that the differences in school achievement of students from advantaged backgrounds and those from disadvantaged backgrounds from a socio-economic, cultural, family background are largely because of insufficient stimulation of intelligence in the first years of life in the case of disadvantaged children. As in the vast majority of states the level of preschool education was not very developed or did not exist, it was necessary to include young children in various educational programs to support them in the learning process"(Cace, coord., 2013, p.59).

It is more likely that the education of poorer students will be of lower quality (World Bank, 2018), only $4 \%$ of new students have parents with a low level of education (European Commission, 2018c).

In 2018, the employment rate of graduates of education and training courses increased slightly, reaching $69 \%$, from $67.2 \%$ in 2017 , but remains well below the EU average (79.5\%). Students enrolled in education and training programs had a limited participation in learning at work, only $10 \%$ of them participating in dual programs: learning and work activity. The vocational education and training system is also affected by a low level of graduation, $11 \%$ of students enrolled in vocational schools in the period 2017-2018 not being promoted in the next school year (NIS, 2019).

Romania does not have good results in terms of skills activation (which measures the transition from education to employment) and skills development. 46.6\% of 15-yearolds perform poorly in mathematics (EU average: 22.4\%), $43.9 \%$ in science (EU average: $21.6 \%$ ) and $40.8 \%$ in reading (EU average: $21.7 \%$ ). The difference between students in urban schools and those in rural schools in terms of average reading score is 110 points, the equivalent of almost three years of schooling (OECD, 2019a).

Participation in higher education is low and remains insufficiently aligned with the needs of the labor market. The university enrollment rate decreased, and in 2018 the tertiary education graduation rate for the 30-34 age group continued to decrease, reaching 24.6\% (EU average: 40.7\%), with women having the highest lower participation rate in the EU (28.1\% compared to $45.8 \%)$. Regional disparities are also high, with a tertiary education graduation level of $38 \%$ in the capital region and between $13 \%$ and $15 \%$ in the other regions. The number of graduates in science, technology, engineering, and mathematics is still particularly low, leading to a shortage 
of qualified staff in the labor market. Although $89 \%$ of tertiary education graduates find a job, many are employed outside their field of specialization (UEFISCDI, 2015).

The acquisition of digital skills remains limited. The number of very well-equipped schools from a digital point of view and of connected schools in Romania is significantly lower than the EU average. Within the e-education Strategy 2023, Romania has launched two major projects, "School Management Information System" and "National Platform for Education", which should contribute to the digitalization of education in over 4,500 schools. Continuing professional development affects the quality and inclusive nature of education. The shortage of teachers persists, with a visible impact on school results. It is still necessary to redesign the initial training of teachers and to strengthen the opportunities for CPD. Initial teacher training provides very limited training and practical training, especially in modern teaching techniques or inclusive pedagogy (OECD, 2017).

Teachers reported high needs for teaching skills in the fields of information and communication technology $(21.2 \%)$, individualized learning $(21.5 \%)$ and teaching for students with special needs (35.1\%). 70\% of teachers report that participation in continuing professional development is hampered by high costs (OECD, 2019b).

\section{Labor force in reality}

After 25 years of economic transformations, the standard of living of the Romanian population is still one of the most critical areas of quality of life. Deliberately maintaining a very low level of income of the majority population in the long run is the key factor in this situation. Thus, with a potential for the labor force reduced by half, the Romanian economy has functioned and still operates at low parameters, not constituting a serious competition for any of the European countries. At the same time, the massive penetration of foreign companies and European products on the domestic market has turned Romania into an extremely profitable economic zone, not only as a market, but also as a cheap labor force, the most cooperative in terms of support for foreign investors. This explains the extremely low level of financial and material resources available to the majority local population, with multiple negative socioeconomic effects - meeting the minimum or perhaps not even the needs in all areas of life: health, education, investment in self-development households, etc.

The capacity of the population to pay on time the current expenses (home maintenance, loan installments, payment of utilities, etc.) is quite low, at the level of 2015. More than a third of households (32.2\%) had repeated arrears, mainly caused by the unsatisfactory financial situation (NIS, 2015). The most frequent arrears were registered for the payment of electricity, the radio subscription $(54.6 \%$ of households with arrears), the maintenance of the home (53.2\%) and the telephone subscription $(34.1 \%)$. Lower shares of arrears were recorded in loan rates $(9.1 \%)$, given that not 
many families can afford to take out a bank loan and, in addition, that such arrears are severely sanctioned.

Relatively few Romanian households (9\%) resort to bank loans. To solve some needs such as: buying installments of some cars, electronic equipment (43.6\%), for repairing or renovating the house $(41.6 \%)$. Loans for other purposes are even lower in share: (4.9\%) for health care, $(4.2 \%)$ for some investments, $(3.4 \%)$ for children's education. Urban households are more likely to borrow $(11.9 \%)$ than rural households $(5.4 \%)$, as well as men (10.4\%) compared to women (5.8\%) (NIS, 2015).

In 2018, almost one in two Romanians cannot cope with unexpected expenses. $9.6 \%$ of the population could not adequately heat their homes (the EU average was 7.3\%). The percentage of the population with arrears on utility bills is also above the EU average (14.4\% compared to $6.6 \%)$. Unemployed households usually go through the most difficult economic situations, the share of those who could not pay their debts on time being $49.3 \%$. The phenomenon of arrears is also more common in households with children, especially in single parents $(48.8 \%)$, but also households with 3 or more dependent children (46.0\%) (NIS, 2019).

\subsection{Population groups exposed to poverty and social exclusion}

Despite higher wages, income inequality increased in 2018. The share of incomes held by the lowest-income segment of the population ( $40 \%$ of the population) in total incomes, which was already one of the lowest in the EU, decreased much more.

Although it continued to decline in 2018, the percentage of people at risk of poverty or social exclusion was still among the highest in the EU, with one in three Romanians being at risk of poverty or social exclusion. The most exposed categories are families with children, the unemployed, the inactive, the atypical workers, the Roma, the elderly, and people with disabilities. In rural areas, this rate is more than twice as high as in cities.

In 2018 , the poverty rate of the employed decreased, but it is still $15.3 \%$. Poverty risks mainly affect rural areas and vulnerable groups and tend to be associated with a low level of education and an unfavorable socio-economic status. Child poverty remains among the highest in the EU, affecting $38.1 \%$ of children compared to the EU average of $24.3 \%$. Social transfers have very little impact on poverty reduction (European Commission, 2019d).

Social conditions continue to improve, but vulnerable groups continue to face significant challenges. The percentage of people exposed to the risk of poverty or social exclusion has decreased even more, reaching in 2018 the lowest level ever recorded, namely $32.5 \%$. Once out of poverty, it is increasingly difficult to get out of it due to its 
high level of transmission from one generation to another and inefficient measures to activate the workforce.

In 2018, the share of incomes of the poorest 40 percent of the population recorded one of the largest declines in the EU, remaining well below pre-crisis levels, $17.6 \%$ compared to the EU average of $21.5 \%$. Children whose parents are low-skilled still face a much higher risk of poverty than children whose parents are highly qualified; in 2018, the difference was 70.7 percentage points, well above the EU average of 43.3 percentage points.

Poverty has fallen but remains among the highest in the EU. In 2018, the poverty of the employed decreased, but remained at a high level of $15 \%$. Causes of this phenomenon include a lack of quality jobs, especially in rural areas, and the precarious situation of the unemployed. The rate of self-employment is high in rural areas, and among the unemployed are a significant percentage of unpaid family workers (in small family businesses).

In 2017, although only $45 \%$ of all employed people lived in rural areas, $82 \%$ of the self-employed and $94 \%$ of family workers lived in rural areas. Most self-employed workers in Romania work in subsistence agriculture, some of them working in the construction sector and others in small family businesses. Increases in the minimum wage have resulted in greater differences between the incomes of employees and those of the self-employed, as their incomes are growing at a slower pace.

Children from rural areas and vulnerable groups have limited access to pre-school education, school education, adequate nutrition, health care and housing. The most disadvantaged are children whose parents have a low level of education and those in households with very low work intensity. Children from Roma communities, those living in rural areas and marginalized urban communities, where access to education and social services is limited, are particularly affected. The decrease in the schooling rate and the increase in the dropout rate for these groups indicate a polarization of education (Ministry of Education, 2019) which could contribute to a higher poverty rate.

People with disabilities have limited access to support services. The rate of people with disabilities exposed to the risk of poverty or social exclusion in Romania is among the highest in the EU (37.6\% compared to the EU average of $28.7 \%$ ). The lack of synergies and complementarity between educational services, employment services and social services further aggravates the situation of this group. In addition, there are no authorized Community services for adults with disabilities (European Commission, 2019i). The deinstitutionalisation of care for adults with disabilities is being implemented at a slow pace, although considerable EU funding is available. Roma also continue to face obstacles in accessing health services due to a lack of identity 
documents, low social security coverage, stigma, and discrimination. The enrollment rate of Roma children in the education system is still below the national average, and the rate of early school leaving is high. Almost a third of the Roma population lives in poor neighborhoods and more than half in overcrowded housing.

The low availability of jobs for low-skilled workers and the positive effect of firms with a higher value chain on economic development mean that advanced skills are needed for the working population to make a positive contribution to reducing regional disparities. The high number of people leaving the education and training system early, such as in the South-East Region (21.3\%) or the North-East Region (19.5\%) and the very low level of training opportunities for adults is still an important issue.

\section{Conclusions}

Regions with a significant share of labor concentrated in low-productivity sectors are characterized by relatively low business dynamics, low wages, and high poverty rates, which has a negative impact on social cohesion. Therefore, the poorer regions of the country risk entering a vicious circle. Existing industries must therefore increase their productivity and higher-growth economic sectors must strengthen their capacity. Education and professional development can make a positive contribution to improving competitiveness if they are more relevant in the market.

The lack of digital connectivity and adequate infrastructure further deepens the disparities between and within regions. Within the regions, the counties where connectivity is low have a low level of economic growth, while the counties where connectivity is good, where significant investment in infrastructure and where foreign direct investment rates are high, the level of economic growth and average salaries are high.

In terms of internet use and internet-related activities, six of the eight regions in Romania are on the last places of the EU ranking, less than $60 \%$ of adults using the internet daily in 2018. The lowest shares are recorded in the Southern-East Region (46\%) and in the North-East Region (45\%) (Eurostat, 2019a).

In terms of digital connectivity, in 2018, only 68\% (EU average - $81 \%$ ) of rural households in Romania had broadband internet access, compared to $80 \%$ (EU average $86 \%$ ) in cities and suburbs and 89\% in large cities (Eurostat, 2019b).

In terms of digital skills, Romania has a large gap between the inhabitants of the city and those in rural areas. In 2017, the digital skills gap was 23 percentage points, while the EU average is 14 percentage points (Eurostat Regional Yearbook, 2019). To address the digital divide at regional level, EU funding has been provided under the 2014-2020 financial framework. Romania's Operational Program for Competitiveness has allocated EUR 100 million from the European Regional Development Fund (ERDF), while the 
Rural Development Operational Program for the period 2014-2020 initially provided for an estimated EUR 25 million from the European Agricultural Fund for Rural Development (EAFRD).

\section{References}

Cace C., Cace S., Nicolăescu V. (2010). Management of the structural funds within the context of the global economic crisis, Review of International Comparative Management, vol.11, no.1: 87-101.

Cace S. (coord.), Neagu G., Raţ C., Ivasiuc A. (2013). Policies for Roma Inclusion in the Member States of the European Union, Strategy and Policy Studies - SPOS 2013, Study no. 2, European Institute of Romania, available at http://ier.gov.ro/wp-content/uploads/publicatii/SPOS_2013_nr.2.pdf

Cepăreanu A. (2020). 2020- a crucial year for the labor market: The threshold of 5 million employees will be reached for the first time in the last 20 years, or not? Financial Newspaper. 04.01.2020. Available at https://www.zf.ro/zf-24/2020-un-an-crucial-pentrupiata-muncii-se-va-atinge-pragul-de-5-mil-de-salariati-pentru-prima-data-in-ultimii-20de-ani-sau-nu-18677589

Neagu G. (2016). Studiu de caz Colegiul Tehnic „Grigore Cobălcescu” - Moineşti, Revista Calitatea Vieţii, XXVII (4): 379.

Neagu G. (2019). Évaluation basèe sur les competences. La Roumanie dans le context europèn, Revista Universitară de Sociologie. 15(1): 86.

CEDEFOP (European Center for the Development of Vocational Training) (2019). Skills panorama (Panorama competențelor). Available at https://skillspanorama.cedefop.europa.eu/en/countries/romania

European Commission (2019b). Taxation Trends in the European Union. Available at https://ec.europa.eu/taxation_customs/sites/taxation/files/taxation_trends_report_2019.pdf

European Commission (2018c). The European Higher Education Area in 2018: Bologna Process Implementation Report. Available at https://op.europa.eu/ro/publicationdetail/-/publication/2fe152b6-5efe-11e8-ab9c-01aa75ed71a1

European Commission (2019d). Joint Employment Report 2020. Available at https://ec.europa.eu/social $/$ main.jsp?catId=738\&langId=en\&pubId $=8270$

European Commission (2019f). Business Survey. Available at https://ec.europa.eu/info/businesseconomy-euro/indicators-statistics/economic-databases/business-andconsumersurveys_en

European Commission (2019g). Digital Economy and Society Index (DESI) 2019- Country report Romania. Available at https://ec.europa.eu/digital-single-market/en/scoreboard/romania

European Commission (2019h). Report on the implementation of national Roma integration strategies 2019. Available at https://ec.europa.eu/info/publications/report-implementation-national-roma-integrationstrategies-2019_en

European Commission (2019i). Monitor of education and training 2019 Romania - Report. Available at https://ec.europa.eu/education/resources-and-tools/document-library/education-and-trainingmonitor-2019-romania-report_ro 
European Commission Brussels (2020). Commission staff working document 2020 Country Report on Romania, SWD (2020) 522 final. Available at https://ec.europa.eu/info/sites/info/ files/2020-european_semester_country-report-romania_ro.pdf

Eurofund (2019). Minimum wages in 2019: Annual Review, available at https://www.eurofound.europa.eu/publications/report/2019/minimum-wages-in2019-annual-review

Eurostat (2019a). 2019 Regional yearbook, available at https:/ec.europa.eu/eurostat/web/ products-statistical-books/-/KS-HA-19-001

Eurostat (2019b). Digital economy and society statistics households and individuals, available at https://ec.europa.eu/eurostat/statistics-explained/pdfscache/33472.pdf

Ministry of Education (2019). Report on the state of pre-university education 2017-2018, available at https://www.edu.ro/sites/default/files/Raport\%20privind\%20starea\%20învățământului\% 20preuniversitar \%20din\%20România_2017-2018_0.pdf

National Institute of Statistics - NIS (2019). The living conditions of the Romanian population 2015, available at https://insse.ro/cms/sites/default/files/field/publicatii/conditiile_de_viata_ale_ populatiei_din_romania_in_anul_2015_1.pdf

OCDE (2017). Review of Evaluation and Assessment in Education: Romania, available at http://www.oecd.org/publications/romania2017-9789264274051-en.htm

OCDE (2019a). PISA 2018 Results, available at http://www.oecd.org/pisa/publications/

OCDE (2019b). Romania: Health Profile in 2019, available at https://www.oecd.org/ publications/ romania-profilul-sanatatii-in-2019-ca3beae6-ro.htm

UEFISCDI (Executive Unit for Financing Higher Education, Research, Development, and Innovation) (2015). Students, Graduates and the Labor Market, available at http://infohe. forhe.ro/wp-content/uploads/2015/01/SAPM-Raport-Final.pdf

World Bank (2018). Romania Functional Review: enhancing the efficiency of public spending in pre-university education, available at http://documents.worldbank.org/curated/en/473931468092366883/ Main-report 